\title{
Executives External Pay Gap, Ownership Concentration and Corporate Performance
}

\author{
Juan Wang \\ Department of Economics and Management, University of Beijing jiaotong, Beijing, China \\ wj1988@vip.sina.com
}

\begin{abstract}
Researches on the influence of external pay gap of executives on corporate performance have not come to a unanimous conclusion, and studies that the ownership structure was involved in their relationship have not been confirmed. This paper attempts to study the influence of external pay gap of executives on the corporate performance as well as the function of ownership concentration on the pay gap from the perspective of external equity. The empirical results show that the positive gap has a positive influence on the corporate performance, and this kind of influence is reduced with the increase in the gap, and the negative pay gap has no significant correlation with the firm performance. Meanwhile, the higher the ownership concentration ratio is, the smaller the executives external pay gap will be. Empirical results indicate that these listed companies in China should raise the pay gap to maintain the incentive energy and the ownership structure reform could bring change in the pay gap.

Index Terms - External pay gap, tournament theory, behavior theory, ownership concentration
\end{abstract}

\section{Introduction}

In recent years, along with the rapid development of China's economy, the big gap of the pay of executives in the same corporation and in different corporations has drawn wide attention and controversy.

In 2005, China began to carry out compulsive requirement for listed companies to disclose the pay of every current director, supervisor and senior administrator, therefore, the management could be informed the pay levels of executives in other listed companies within the same industry. In this context, the comparison of the external equity of pay gap will exert psychological and behavioral impact on the corporate executives, thus influencing the corporate performance by adjusting management behavior.

The existing literature mainly focused on the fairness of executive internal pay, little refer to the external equity, especially in the empirical area. Therefore, in our present economic system and under the current cultural background, as well as the broad interest in the executive compensation issues, it's necessary to study the executive external pay fairness impact on firm performance based on the data of China listed companies. Seeking answers to these questions can not only advance the development of the theory of corporate salary, but also helps to understand, evaluate and formulate our company's current executive compensation system objectively.

\section{Literature Review}

A. Positive impact of pay gap on corporate performance

Lazear and Rosen ${ }^{[1]}$ first proposed the tournament theory in 1981.They think that increasing the pay gap between CEO and other employees will reduce the monitoring cost towards the agents. It can provide positive incentives to consistency interests between principal and agent and ultimately improve firm performance. Winter-Ebmer and Zweimfiller (1999) studied the panel data from 1975-1991 in Belgian labor market, using the standard deviation of remuneration function on firm-level as a proxy variable for the unfair pay. It also support the positive correlation between the pay gap and corporate performance. Kin Wai Lee, etc. (2007) ${ }^{[2]}$ first concern the regulatory role of corporate governance in pay equity and performance. The empirical results support the tournament theory and found that the correlation is stronger in the companies with higher agency costs.

\section{B. Negative impact of pay gap on corporate performance}

Envy which generated by compensation comparison will lead managers to pursuit of scale in the business process and occur inefficient investment. Goel and Thakor $(2005)^{[3]}$ first studied manager's envy on the impact of investment from the point of view of internal equity. They found that the executives with psychology of envy tend to overinvest. Gilles Grolleau (2006) put envy into two different kinds, the positive envy "white envy" and the negative one "black envy". Negative envy executive will occupy more resources from be envied executives by non-efficiency investment. Per (2007) also studied the compensation deviation in the same industry of Swedish companies from inside and outside perspective, found that the influence of pay external fairness is greater than internal fairness.

\section{Ownership structure and executive compensation}

Shleifer and Vishny (1986) thought that the ownership and control will separate when the ownership structure is dispersed. Shareholders presence "free rider" behavior in the process of overseeing executives. With the increase of the proportion of large shareholders, major shareholders will increase the power of supervisory. Grossman and Hart (1998) ${ }^{[4]}$ shows that in dispersed ownership structure conditions, single shareholder will not involved in corporate governance actively. Formulation and conduct of executive compensation is more freedom, resulting in relatively poor firm performance.

\section{Research Design}

Adams' equity theory states that people tend to compare themselves with others similar to them, so do the industry 
executives. According to the different directions of comparisons, the upward comparison is drawn between themselves and more outstanding counterparts, and the downward comparison is made between themselves and inferior ones. Results of the comparison are individuals will reduce their levels of self-awareness in upward comparisons, or will raise their levels of self-evaluation in downward comparisons (Blanton, 2004) $)^{[5]}$. However, it does not mean that the bigger the positive pay gap is, the better the performance is. Pindyck and Rubinfeld (1997) argued in their discussion of people's risk appetite that the utility was decreasing as the salary increased, especially when employees reached a certain level, such as the management of the enterprise in which the phenomenon was particularly evident. Based on the above conclusions, Assumption 1 is proposed as follows:

H1: Positive external gap between executives is significantly positively related to a corporate's performance next year, and the positive incentive effect will reduce with the increase of the positive pay gap.

When the management finds their pay levels lower than others in the industry, they may make an effort to improve company performance. The reason is: the negative additional pay often represents a warning or punishment signal from the directors to the management. Moreover, under the conditions of pay disclosure, management pay is often an important basis for investors to determine the ability of the company's management. On the other hand, upward comparison results in a lower self-evaluation of managers and the production of envy, such a sense of unfairness may be reflected in a number of ways, including the most typical way which is the negative behavior in the process of managing.

Accordingly, in terms of both aspects, negative additional pay may fail to exert significant influence on the performance of the company. Assumption 2 is proposed as follows:

$\mathrm{H} 2$ : The negative pay of executives is not significantly correlated to the corporate performance.

Shleifer and Vishny $(1986)^{[6]}$ believed that ownership concentration may have an impact on executive pay levels. As mentioned earlier, when it is dispersed, the social cost of monitoring the CEO by the individual shareholder is high. But in a relatively concentrated ownership structure, major shareholders have sufficient capacity and motivation to monitor executives, thus inclining to support decisions and programs of the direct monitoring of the management, rather than choose a larger pay gap in order to avoid the resulting unfairness. Assumption 3 is proposed as follows:

H3: Ownership concentration bears significant negative relationship with positive pay gap.

As the pay gap can be divided into positive one and negative one, and it is denoted by its absolute value, assumption 4 is proposed as follows:

H4: Ownership concentration bears significant positive relationship with negative pay gap.

\section{Study Design}

\section{A. Variable selection}

\section{1) Dependent variable}

Corporate performance (ROA): corporate performance refers to the business performance, reflecting the allocation and operating of resource efficiency. This article uses the total annual return on assets (ROA) to measure firm performance. ROE is used in robustness tests.

\section{2) Arguments}

External executives pay gap (GAP): We use the difference between the top three executive pay and the industry average top three executive pay as a measure to describe the external fairness variables. According to Zhang zhengtang $(2007)^{[7]}$, executives external pay gap often affect firm's performance in next year, so we use a first-order lag of pay gap to describe the variable.

Ownership concentration (H3): We use Herfindahl index to describe the degree of ownership concentration, selecting the square of the proportion of the top three shareholders.

\section{3) Control Variables}

Corporate continuity financing capacity (LEV): China's listed companies mainly rely on bank loans for financing. Therefore, we use asset-liability ratio (LEV) as a control variables to describe the sustained financing capacity.

Sales margin (SPR): Nissim and Penman (2001) found that sales margin is one of the motives for company growth, it plays an important role in the prediction of the companies' performance.

Operating profit growth (GROW): a key indicator to measure the corporate annual operating profit growth, having a good representation for the corporate growth.

Corporate size (SIZE): corporate total asset is relatively stable. In this paper, the natural logarithm of the total assets is used to describe the firm size.

Number of independent directors (SOLO): A Board which has the majority of independent directors will have differences in behaviors with the board which do not have independent directors

In summary, the variables are as defined in Table I.

TABLE I Indicators selected and defined

\begin{tabular}{|l|l|}
\hline \multicolumn{1}{|c|}{ Symbol } & \multicolumn{1}{|c|}{ Explained } \\
\hline ROA & Net profit / Total assets \\
\hline ROE & Net profit / Net assets \\
\hline GAP & $\begin{array}{l}\text { Three corporate executive pay - the industry average of three } \\
\text { executive pay }\end{array}$ \\
\hline LEV & Enterprise Total Liabilities / total assets \\
\hline SIZE & Ln (total assets $)$ \\
\hline SPR & Net profit / Sales \\
\hline GROW & $\begin{array}{l}\text { (Current enterprise operating profit / corporate operating } \\
\text { profits last year }-1) * 100 \%\end{array}$ \\
\hline H3 & ratio squared of the first three major shareholders \\
\hline SOLO & The number of independent directors \\
\hline
\end{tabular}




\section{B. Model Design}

In order to study the effect of ownership concentration on the external pay gap, we use positive and negative external pay gap as dependent variables, ownership concentration as an explanatory variable, to build model I. Then use corporate performance as dependent variables, the logarithmic of a firstorder lag of the external executive pay gap as explanatory variables. Model II is built as follows:

$$
\begin{aligned}
& G A P_{i, t}=\alpha+\beta_{1} H 3_{i, t}+\beta_{2} L E V_{i, t}+\beta_{3} S I Z E_{i, t} \\
& +\beta_{4} S C A L E_{i, t}+\beta_{5} S P R_{i, t}+\beta_{6} S O L O_{i, t}+\mu_{i, t} \\
& \operatorname{ROA}_{i, t}=\alpha+\beta_{1} L N(G A P)_{i, t-1}+\beta_{2} S C A L E_{i, t}+\beta_{3} L E V_{i, t} \\
& +\beta_{4} S_{I Z E_{i, t}}+\beta_{5} S_{S O L O}+\beta_{6} G R O W_{i, t}+\mu_{i, t}
\end{aligned}
$$

\section{Empirical Research}

\section{A. Sample selection}

In China's listed companies, due to government direct control, the executives pay level of state-owned enterprise is not defined in accordance with the principles of the market. The majority of small and medium enterprise board are private enterprises, the executives pay mainly depend on market, so we choose the financial data from small and medium enterprise board to study the relationship between the pay gap of executives and firm performance. For the elimination of trade gap, the selected listed companies are all from manufacturing industry. We screen and use the data from 2005-2009 to analysis and regress. In order to ensure data quality, we eliminate individual outliers which will have an impact on the conclusion of the study.

\section{B. Descriptive Statistics}

The descriptive statistics of variables from table II and table III show that the maximum of positive pay gap reach $8,145,690$ yuan with the average gap is 815,730 yuan, which is significantly greater than the maximum of the negative pay gap. The maximum of negative pay gap is 1,034,560 yuan and the average of pay gap is 395,520 yuan. It's indicating that the executive pay of most companies is higher than the industry average. From the aspect of corporate performance, we can see that corporate performance is generally low with more volatile data in companies of which executive pay is lower than industry average. To the pay above-average corporates, the mean corporate size is 21.066 , higher than the one with pay below-average, which is 20.758 . There is a big difference in asset-liability ratio. The maximum of it is 1.293 and the minimum is 0.029 . The number of independent directors is 15 , with an average of three people. For ownership concentration, the maximum is 0.566 , the minimum is 0.013 , there is a big difference between different enterprises. The number of the positive external pay sample is 250 , while the number of negative sample is 565 .
TABLE II Descriptive statistics of relevant variables (positive external pay gap sample: thousand)

\begin{tabular}{|l|c|c|c|c|c|}
\hline variable & $\max$ & mini & variance & mean & median \\
\hline GAP & 814.569 & 0.5436 & 152.965 & 81.573 & 45.693 \\
\hline ROA & 0.285 & -0.172 & 0.003 & 0.088 & 0.087 \\
\hline SIZE & 24.057 & 19.204 & 0.050 & 21.066 & 21.000 \\
\hline SCALE & 0.520 & -1.866 & 0.025 & 0.132 & 0.104 \\
\hline GROW & 22.258 & 120.524 & 0.571 & -0.460 & 0.039 \\
\hline LEV & 0.805 & 0.047 & 0.010 & 0.342 & 0.315 \\
\hline SOLO & 5 & 2 & 0.034 & 3.269 & 3 \\
\hline H3 & 0.547 & 0.016 & 0.102 & 0.173 & 0.153 \\
\hline
\end{tabular}

TABLE III Descriptive statistics of relevant variables (negative external pay gap sample:thousand )

\begin{tabular}{|l|c|c|c|c|c|}
\hline variable & $\max$ & mini & variance & mean & median \\
\hline GAP & -0.424 & -103.456 & 22.946 & -39.55 & -39.34 \\
\hline ROA & 0.464 & 0.729734 & 0.073 & 0.055 & 0.053 \\
\hline SIZE & 23.173 & 19.237 & 0.669 & 20.785 & 20.732 \\
\hline SCALE & 0.624 & -4.642 & 0.253 & 0.012 & 0.071 \\
\hline GROW & 27.572 & -131.632 & 7.838 & -0.608 & -0.038 \\
\hline LEV & 1.293 & 0.029 & 0.181 & 0.409 & 0.425 \\
\hline SOLO & 1 & 5 & 0.546 & 3.135 & 3 \\
\hline H3 & 0.013 & 0.566 & 0.108 & 0.175 & 0.147 \\
\hline
\end{tabular}

\section{Correlation analysis}

Table IV shows that the pay gap is significantly related to corporate performance at the $1 \%$ level, also have a significant relationship with ownership concentration. The hypothesis expected is supported preliminarily by the significant correlation between the factors, the specific relationship will be further verified in the regression results. Explanatory variables in the regression model do not exist a high correlation, VIF is less than 4, indicating that there's little effect of multicollinearity.

\section{Empirical Test}

Using least squares regression model, the model I empirical results is shown in Table V. The ownership concentration is significantly negative relative to the positive pay gap and significant positive to the absolute value of the negative pay gap. The higher the ownership concentration is, the lower the corporate executive pay level exists. The results meet the expectation of hypothesis 3 and hypothesis 4 . It also shows that the executive pay level is higher in large enterprises.

As the pay gap can be divided into positive one and negative one, and it is denoted by its absolute value. As shown in Table VI, the estimated coefficient of positive pay gap is significantly positive, indicating that it has significant positive effect on the performance of the enterprise. Due to the fact that the natural logarithm of positive external pay gap is regarded as an explanatory variable in the model, the influence of positive external pay on corporate performance is decreasing gradually. 
Tab IV Variable correlation analysis

\begin{tabular}{|l|l|l|l|l|l|l|l|l|}
\hline & ROA & H3 & SIZE & SCALE & GROW & LEV & SOLO & GAP \\
\hline ROA & 1.0000 & & & & & & & \\
\hline H3 & 0.0101 & 1.0000 & & & & & & \\
\hline SIZE & $0.0718^{* * *}$ & $0.1264^{* * *}$ & 1.0000 & & & & & \\
\hline SCALE & $0.3371^{* * *}$ & -0.0240 & 0.0009 & 1.0000 & & & & \\
\hline GROW & $0.1815^{* * *}$ & 0.0512 & 0.0436 & $0.0626^{*}$ & 1.0000 & & & \\
\hline LEV & $0.4478^{* * *}$ & -0.0569 & $0.3606^{* * *}$ & $-0.1966^{* * *}$ & $-0.0975^{* *}$ & 1.0000 & & \\
\hline SOLO & $-0.1257^{* *}$ & -0.0464 & $0.1585^{* * *}$ & -0.0490 & 0.0346 & $0.1488^{* * *}$ & 1.0000 & \\
\hline PAY & $0.2447^{* * *}$ & $-0.0661^{*}$ & $0.2941^{* * *}$ & $0.0797^{* *}$ & 0.0302 & $-0.0947^{* * *}$ & 0.0204 & 1.0000 \\
\hline
\end{tabular}

Note: $* * *, * *, *$ denote was significantly associated at the $1 \%, 5 \%, 10 \%$ level

Tab V Regression inspection of model I

\begin{tabular}{|l|c|c|}
\hline & Positive pay gap & Negative pay gap \\
\hline H3 & $-2.3360^{* * *}$ & $1.2430^{* * *}$ \\
\hline & $(-2.17)$ & $(2.93)$ \\
\hline SIZE & $0.9368^{* * *}$ & $-0.1837^{* *}$ \\
\hline SCALE & $(6.91)$ & $(-2.39)$ \\
\hline & -0.1068 & 0.0122 \\
\hline GROW & $(-0.47)$ & $(-0.22)$ \\
\hline & 0.0155 & $-0.1300^{* *}$ \\
\hline LEV & $(1.52)$ & $(2.13)$ \\
\hline & $-2.3085^{* * *}$ & $0.7359^{* * *}$ \\
\hline SOLO & $(-3.40)$ & $(2.08)$ \\
\hline & -0.2510 & -0.1029 \\
\hline CONS & $(-1.40)$ & $(-1.26)$ \\
\hline & $-4.8824^{* * *}$ & $6.2112^{* * *}$ \\
\hline$N$ & $(-3.79)$ & $(5.62)$ \\
\hline adjust $\mathrm{R}^{2}$ & 565 & 565 \\
\hline F & 0.22 & 0.31 \\
\hline
\end{tabular}

Note: $* * * * *, *$ denote was significantly associated at the $1 \%, 5 \%, 10 \%$ level

Tab VI Regression inspection of model II

\begin{tabular}{|l|c|c|c|c|}
\hline & \multicolumn{2}{|c|}{ Positive pay gap } & \multicolumn{2}{c|}{ Negative pay gap } \\
\hline & ROA & ROE & ROA & ROE \\
\hline GAP & $0.0108^{* * * *}$ & $0.0096^{* * *}$ & -0.0005 & 0.0004 \\
\hline SIZE & $(3.21)$ & $(2.66)$ & $(-0.30)$ & $(0.17)$ \\
\hline & $0.0126^{* *}$ & $0.0110^{*}$ & 0.0052 & 0.0057 \\
\hline GROW & $(2.03)$ & $(1.64)$ & $(1.63)$ & $(1.39)$ \\
\hline & $0.000730^{*}$ & 0.000772 & 0.0003 & $0.0004^{*}$ \\
\hline SCALE & $(1.70)$ & $(1.67)$ & $(1.62)$ & $(1.68)$ \\
\hline & $0.0215^{* *}$ & $0.0241^{* *}$ & $0.4763^{* * *}$ & $0.4557^{* * *}$ \\
\hline SOLO & $(2.26)$ & $(2.35)$ & $(19.14)$ & $(14.02)$ \\
\hline & $-0.0191^{* *}$ & $-0.0168^{*}$ & -0.0039 & -0.0042 \\
\hline LEV & $(-2.60)$ & $(-2.11)$ & $(-1.17)$ & $(-0.96)$ \\
\hline & $-0.149^{* * *}$ & $-0.157^{* * *}$ & -0.0101 & -0.0091 \\
\hline CONS & $(-5.11)$ & $(-4.98)$ & $(-0.61)$ & $(-0.42)$ \\
\hline & $-0.200^{* *}$ & $-0.156^{* * *}$ & $-0.0669^{*}$ & $-0.0911^{*}$ \\
\hline$N$ & $(-2.77)$ & $(-3.28)$ & $(-1.99)$ & $(-1.83)$ \\
\hline adjust $\mathrm{R}^{2}$ & 250 & 250 & 565 & 565 \\
\hline F & 0.31 & 0.29 & 0.28 & 0.22 \\
\hline
\end{tabular}

Note: $* * *, * *, *$ denote was significantly associated at the $1 \%, 5 \%, 10 \%$ level
ROE is used to conduct robustness test and the same result supports the hypothesis 1 . Meanwhile the estimated coefficient of negative pay gap is not significant, indicating that it has no significant correlation with corporate performance, supporting Hypothesis 2. In addition, the regression results of other variables are very reasonable. The sales margin and corporate performance are significantly and positively correlated, which is consistent with the findings of Nissim and Penman (2001). Under the condition of forward pay gap, the company size is significantly associated with corporate performance, indicating the positive pay gap has a greater influence in large companies. Meanwhile, the negative correlation between the proportion of independent directors and corporate performance is also thought-provoking, for the internal directors master the firm-specific knowledge and information and too many independent directors may affect the agency relationship between shareholders and executives, therefore, to keep a certain percentage of inside directors is valuable.

\section{Main Conclusions and Implications}

The empirical results bring some enlightenment for the remuneration development. When the external pay gap exists, increasing pay level moderately will conducive to improvement the corporate performance, while external pay gap is negative, the remuneration shows a certain degree of "rigid" and reducing the salary can't play nice warning. Meanwhile conclusion shows that ownership concentration will affect the external pay gap between executives. Equity restructuring, to improve the dispersion of equity will be beneficial to improve the executive pay level. Specifically, we should focus on the situation which equity is too concentrated. For the specific listed companies, based on the industry it belongs to, its life cycle, size and also the need of national macro-control, after carefully trading off between the factors which would affect ownership concentration, we can choose the optimal concentration of ownership degrees.

\section{References}

[1] Lazear, E. and Rosen, S. "Rank-order Tournaments as Optimum Labor Contracts," Journal of Political Economy, May 1981.

[2] KinWai Lee, Baruch Lev, Gillian Hian Heng Yeo, "Executive pay dispersion, corporate governance, and firm performance," Review of Quantitative Finance and Accounting: pp. 315-338, April 2008.

[3] Anjan V. Thakor, Anand M. Goel,"'Green with Envy: Implications for 
Corporate Investment Distortions," Vol. 78, November 2005.

[4] Grossman. Hart, "Corporate Ownership Around the World," Journal of Finance, pp. 471-517, 1999 (54).

[5] DA Stapel, H Blanton, "From Seeing to Being: Subliminal Social Comparisons Affect Implicit and Explicit Self-Evaluations," vol. 87, pp. $468-481,2004$.
[6] Andrei Shleifer, Robert W. Vishny, "Large shareholders and corporate control," Journal of Political Econom, Volume 94,Issue 3,pp.461488,June, 1986

[7] Zhangzheng Tang, "core members of the senior management team pay gap and corporate performance effect relationship," Economics and Management, pp.16-25, Feb 2008. 